Literature Review

\title{
Fiber consumption effect on non-communicable disease: How big is the impact?
}

Yuli Indarti*

Programme Study of PIAUD, Faculty of Tarbiyah and Education, IAIN Jember

A R T I C L E I N F O

\section{Submitted : April 2019 \\ Accepted : August 2019 \\ Published : January 2020}

\section{Keywords:}

fiber, cardiovascular disease, diabetes mellitus, cancer, supplement

\section{*Correspondence:}

yuli.indarti@iain-jember.ac.id

\begin{abstract}
Non-communicable diseases have effects on the quality of human resources because, in addition to causes of death and morbidity, they also reduce productivity. Fiber intake was allegedly affecting the incidence of non-communicable diseases. The purpose of this literature review is to look at the link between fiber intake and the incidence of noncommunicable diseases and the effect of fiber supplements to treat non-communicable diseases. Several literature indicate that fiber intake is associated with cardiovascular disease, diabetes mellitus, cancer, and obesity. Research also shows fiber supplementation can improve metabolic profiles, blood sugar, insulin resistance in cardiovascular and diabetes mellitus patients. Fiber supplementation also reduces the risk of breast cancer. Fiber intake is related to the incidence of non-communicable diseases and can overcome some non-communicable diseases
\end{abstract}




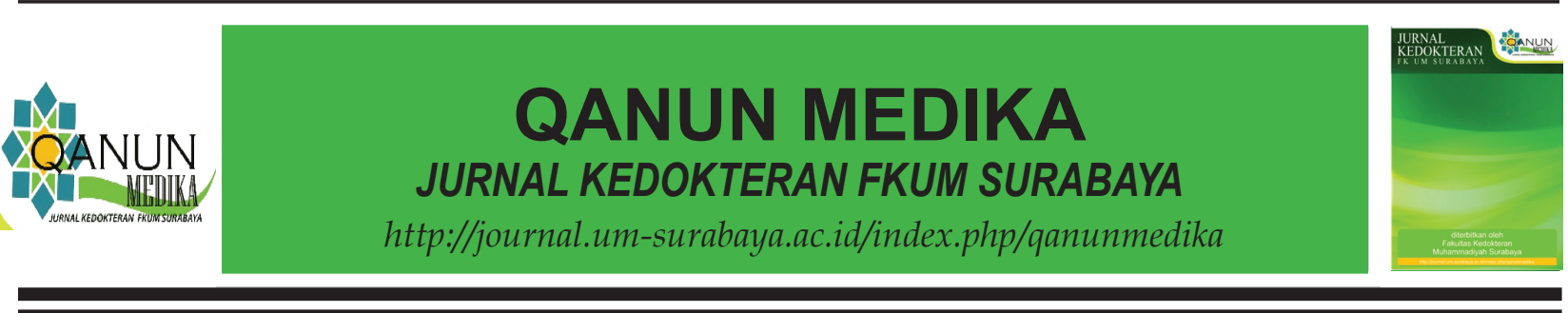

\section{INTRODUCTION}

Indonesia's national development goals are inseparable from the development of human resources, therefore, improving the quality of human resources is part of the development process. While the impact of non-communicable diseases on the resilience of human resource is tremendous because it causes death, morbidity, and decrease in productivity. In the 2015-2019 National Medium Term Development Plan (Rencana Pembangunan Jangka Menengah Nasional or RPJMN) it was stated that the reduction target of the prevalence of high blood pressure was $25.8 \%$ in the initial year (2015) to $23.4 \%$ (2019). The prevalence of overweight and obesity in 18-year-old residents is also sought to remain stable as the initial incidence is 28.9\% (Bappenas, 2015).

Non-communicable diseases are currently the government's primary concern because besides being the leading cause of death, the prevalence tends to increase. Based on the results of the 2018 Riskesdas, the incidence of hypertension as much as $34.1 \%$ increased from the 2013 Riskesdas, which was $25.8 \%$, while the prevalence of Diabetes Mellitus was $8.5 \%$, higher than the previous $6.9 \%$ (Kemenkes, 2018).

The existence of the epidemiological transition from infectious diseases to noncommunicable diseases is estimated due to socio-economic, environment, and population structure changes. People have adopted unhealthy lifestyles, such as smoking, lack of physical activity, harmful eating patterns, and alcohol consumption, which are the risk of non-communicable diseases (Bonita, 2013).

In terms of diet, it is estimated that there are risk factors for non-communicable diseases, especially fiber intake. Based on the results of the 2013 Riskesdas, $93.5 \%$ of Indonesian fruit and vegetable consumption is still lacking. Therefore, it is assumed that fiber diets are also lower than WHO recommendations, 25-35 grams per day.

\section{LITERATURE REVIEW}

\section{Fiber Definition and Composition}

Dietary fiber is a part of plants including carbohydrates, which cannot be digested and absorbed in the small intestine, either entirely or partially fermented in the large intestine of humans. They include polysaccharides, oligosaccharides, lignin, and related plant substances (Prosky, 2001). Intake of dietary fiber has been reported to be beneficial in reducing serum cholesterol and blood pressure. Therefore, it is believed that a lack of dietary fiber can contribute to the epidemic of cardiovascular disease.

Different compositions of various fibers explain the diversity of functions, including water retention capacity, absorption properties (bile salt binding capacity, glucose, and fat absorption), tendency to form gels, viscosity, fermentability and the ability to modify the composition of intestinal microbiota. These components can reduce metabolism and change certain CHD risk factors, improve CHD prognosis, and reduce the probability of cardiovascular events (Bocanegra, 2009). Generally, Dietary Fiber (DF) is grouped based on solubility in water, water-soluble dietary fiber (pectin, pectins, gums, and mucilages and storage polysaccharides) and dietary fiber insoluble in water (cellulose, hemicellulose and lignin) (Papathanasopoulos, 2010) . One source of potentially rich dietary fiber is whole grain products. Intake of whole grains is positively related to health.

This article is a review of the results of research studies and meta-analyzes that assessed the relationship between fiber and non-communicable diseases that are widely published. It also discusses about cardiovascular 
disease, diabetes mellitus, and cancer, or biomarkers that are considered to contribute to the disease such as lipid profiles (TG, TC, LDL-C, HDL-C), insulin resistance, and blood pressure.

\section{Fiber and Cardiovascular Disease}

Most of the studies showed that fiber intake affected the occurrence of cardiovascular disease. Research from four meta-analyses of the effect of fiber diet and the risk of cardiovascular disease has been found by Rae (2017), Wei et al. (2017), Kim and Je (2015) and Wu et al. (2014). Mc. Rae (2017) found a significant reduction in cardiovascular disease mortality, as well as the incidence of cardiovascular disease, coronary heart disease, and strokes on a high-fiber diet. Wei et al. (2017) showed there was a curvilinear relationship found between fiber consumption and the prevalence of Metabolic Syndrome (MetS). Compared with non-fiber intake, OR Metabolic Syndrome at all levels of fiber intake were 0.85 for the intake of $10 \mathrm{~g} / \mathrm{d}$ and 0.73 for the intake of $40 \mathrm{~g} / \mathrm{d}$.

Wu et al. (2015) proved that fiber diets based on fiber subtypes (cereals, fruit, and vegetable fiber) were also shown to reduce the risk of coronary events, where the RR of all coronary events was $0.93(p=0.001)$ and $0.83(p=0.001)$ for mortality. According to Kim and Je (2015), the RR (Relative Risk) of CVD and CHD were 0.77 and 0.76 , respectively, for the highest versus lowest dietary fiber category.

Other studies that show similar results to those of the meta-analysis were researched by Park et al. (2011), Tayyem et al. (2017) and Xu et al. (2016). Threapleton et al. (2013) have different findings, which is fiber intake is not associated with fatal CHD, stroke, or cardiovascular disease risk (CVD). However, it shows the possibility of protection of cereal fiber at risk of fatal stroke in women with excess weight. Xu et al. (2016) said that the ratio of protein and fiber intake significantly affected the incidence of CVD, where the protein-fiber ratio was 1.15 times higher than the average, would increase Hazard Ratio. Dietary fiber is not significantly associated with CVD events.

\section{Fiber and Diabetes Mellitus}

Effect of fiber intake on the risk of diabetes mellitus is estimated through intermediate outcomes/biomarkers (e.g., blood sugar). Research by Fuji et al. (2013) found a highfiber diet reduced cardiovascular risk in patients with diabetes mellitus. A high-fiber diet also has a negative relation with blood sugar and metabolic syndrome (Cholesterol levels, Glucose, HOMA-IR, blood pressure). Goff et al. (2017) also found a high-fiber diet associated with a decrease in blood sugar, thus decreasing the risk of Diabetes Mellitus Type 2 (DMT2).

\section{Fiber and Cancer}

The effect of fiber intake on cancer has been shown in several meta-analysis studies including a meta-analysis by Dong et al. (2011), where the RR of breast cancer between the highest dietary fiber intake compared with the lowest was $p=0.444$. A significant result is shown by Aune et al. (2011) in a meta-analysis study where RR for the highest versus lowest intake at risk of breast cancer was $0.93(\mathrm{p}=$ 0.00 ). Based on a meta-analysis by Kim and Je (2015), the highest dietary fiber intake shown the risk of death of all types of cancer was 0.86 times lower than the lowest intake.

Another result of this study is the effect of fiber on esophagus cancer, where Coleman et al. (2013) proved that there was a significant relationship between the highest fiber intake with esophagus cancer. Similar results showed that regular fiber intake reduced the risk of esophagus cancer (Tang et al. (2013). Zhang 


\section{QANUN MEDIKA \\ JURNAL KEDOKTERAN FKUM SURABAYA \\ http://journal.um-surabaya.ac.id/index.php/qanunmedika}

Table 1. 1 Research Summary on The Effects of Fiber on Non-Communicable Diseases

\begin{tabular}{|c|c|c|c|c|c|c|}
\hline NO & SOURCE & DESIGN & SAMPLE & VARIABLE & OUTCOME & CONCLUSION \\
\hline 1. & $\begin{array}{l}\text { McRae } \\
(2017)\end{array}$ & $\begin{array}{l}\text { Meta- } \\
\text { Analysis }\end{array}$ & Adults & Fiber diet & $\begin{array}{l}\text { Cardiovascular } \\
\text { diseases }\end{array}$ & $\begin{array}{l}\text { There is a statistically } \\
\text { significant decrease in } \\
\text { (RR) cardiovascular } \\
\text { disease mortality, as } \\
\text { well as the incidence } \\
\text { of cardiovascular } \\
\text { disease, coronary heart } \\
\text { disease and stroke in } \\
\text { those with a high-fiber } \\
\text { diet }\end{array}$ \\
\hline 2. & $\begin{array}{l}\text { Wei et al. } \\
\text { (2017) }\end{array}$ & $\begin{array}{l}\text { Meta- } \\
\text { Analysis }\end{array}$ & $\begin{array}{l}\text { Adults } \\
(\mathrm{n}=28241)\end{array}$ & $\begin{array}{l}\text { Fiber diet } \\
\text { Coronary } \\
\text { artery disease } \\
\text { risk and } \\
\text { Stroke }\end{array}$ & $\begin{array}{l}\text { Metabolic } \\
\text { syndrome }\end{array}$ & $\begin{array}{l}\text { There was a } \\
\text { curvilinear } \\
\text { relationship found } \\
\text { between fiber } \\
\text { consumption and the } \\
\text { prevalence of } \\
\text { Metabolic Syndrome. }\end{array}$ \\
\hline 3. & $\begin{array}{l}\text { Wu et al. } \\
(2014)\end{array}$ & $\begin{array}{l}\text { Meta- } \\
\text { Analysis }\end{array}$ & $\begin{array}{l}\text { Adults } \\
(n=672408)\end{array}$ & $\begin{array}{l}\text { Fiber diet by } \\
\text { type } \\
\text { Coronary } \\
\text { artery disease } \\
\text { risk and } \\
\text { Stroke }\end{array}$ & $\begin{array}{l}\text { Risk of } \\
\text { coronary events } \\
\text { and CHD } \\
\text { mortality }\end{array}$ & $\begin{array}{l}\text { There is a significant } \\
\text { relationship between } \\
\text { fiber intake and CHD } \\
\text { incidence and } \\
\text { mortality }(\mathrm{p}<0.001)\end{array}$ \\
\hline 4. & $\begin{array}{l}\text { Kim and Je } \\
(2015) \\
\text { Meta- } \\
\text { Analysis } \\
\text { Study - Diet }\end{array}$ & $\begin{array}{l}\text { Meta- } \\
\text { Analysis }\end{array}$ & - & Fiber diet & $\begin{array}{l}\text { CVD and the } \\
\text { risk of death } \\
\text { due to all types } \\
\text { of cancer }\end{array}$ & $\begin{array}{l}\text { Dietary fiber reduces } \\
\text { the RR of CVD, } \\
\text { CHD, and the risk of } \\
\text { death from all types }\end{array}$ \\
\hline 5. & $\begin{array}{l}\text { Park, et al. } \\
\text { (2011) }\end{array}$ & $\begin{array}{l}\text { Cohort } \\
\text { Prospec } \\
\text { tive }\end{array}$ & $\begin{array}{l}\text { CHD patient } \\
(\mathrm{n}=219.123 \\
\text { males and } \\
168.999 \\
\text { females })\end{array}$ & Food fiber & $\begin{array}{l}\text { Risk of death } \\
\text { due to CHD }\end{array}$ & $\begin{array}{l}\text { Dietary fiber intake } \\
\text { reduce the risk of } \\
\text { death from CHD }\end{array}$ \\
\hline
\end{tabular}

\begin{tabular}{|c|c|c|c|c|c|c|}
\hline 6. & $\begin{array}{l}\text { Tayyem et al. } \\
\text { (2017) }\end{array}$ & $\begin{array}{l}\text { Case- } \\
\text { Control }\end{array}$ & CHD patient & $\begin{array}{c}\text { Fiber dietary } \\
\text { pattern }\end{array}$ & CHD Risk & $\begin{array}{l}\text { Fiber high diets } \\
\text { significantly } \\
\text { reduce the odds of } \\
\text { CHD (OR }=0.55 \text {, } \\
95 \% \mathrm{CI}=0.27 \text { - } \\
0.92)\end{array}$ \\
\hline 7. & $\begin{array}{l}\text { Xu et al. } \\
(2016)\end{array}$ & $\begin{array}{l}\text { Prospectiv } \\
\text { e Cohort }\end{array}$ & $\begin{array}{l}\text { Male adults } \\
\text { with CKD } \\
\text { (Chronic } \\
\text { Kidney } \\
\text { Disease) } \\
(\mathrm{n}=390)\end{array}$ & $\begin{array}{l}\text { Protein diet, } \\
\text { fiber diet, } \\
\text { and the ratio } \\
\text { of protein } \\
\text { and fiber } \\
\text { diets }\end{array}$ & CVD Event & $\begin{array}{l}\text { Protein intake ratio- } \\
\text { fiber associated with } \\
\text { CVD incidence. } \\
\text { Food fiber only is not } \\
\text { significantly } \\
\text { associated with CVD } \\
\text { events }\end{array}$ \\
\hline
\end{tabular}




\begin{tabular}{llllll}
\hline $\begin{array}{l}\text { 8. Threapleton } \text { et } \\
\text { al. (2013) }\end{array}$ & $\begin{array}{l}\text { Cohort } \\
\text { Prospective }\end{array}$ & $\begin{array}{l}\text { CVD patient } \\
(\mathrm{n}=31,036 \\
\text { women })\end{array}$ & Fiber diet & $\begin{array}{l}\text { CHD dan Stroke } \\
\text { risk }\end{array}$ & $\begin{array}{l}\text { Total dietary fiber } \\
\text { and fiber from } \\
\text { different food sources } \\
\text { not related to fatal }\end{array}$ \\
& & & & $\begin{array}{l}\text { CHD, stroke or CVD } \\
\text { risk }\end{array}$
\end{tabular}

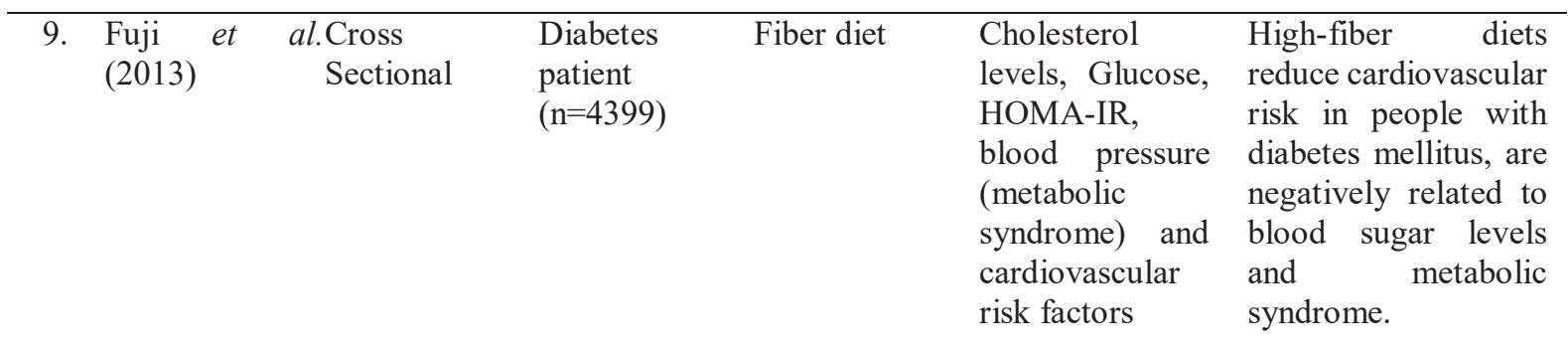

\begin{tabular}{|c|c|c|c|c|c|c|}
\hline 10. & $\begin{array}{l}\text { Goff } \\
\text { et al. (2017) }\end{array}$ & $\begin{array}{l}\text { Cross- } \\
\text { Sectional }\end{array}$ & Adults & Fiber diet & Glucose levels & $\begin{array}{l}\text { A high-fiber intake is } \\
\text { associated with a } \\
\text { decrease in blood } \\
\text { sugar so that reducing } \\
\text { the risk of DMT2 }\end{array}$ \\
\hline 10. & $\begin{array}{l}\text { Dong et } a l \text {. } \\
(2011)\end{array}$ & $\begin{array}{l}\text { l. Prospectiv } \\
\text { e Cohort }\end{array}$ & $\begin{array}{l}\text { Woman } \\
(\mathrm{n}=712,195)\end{array}$ & Fiber diet & Breast cancer & $\begin{array}{l}\text { There was a decrease } \\
\text { in RR breast cancer } \\
\text { between the highest } \\
\text { compared to the } \\
\text { lowest dietary fiber } \\
\text { intake }\end{array}$ \\
\hline
\end{tabular}

\begin{tabular}{|c|c|c|c|c|c|c|}
\hline & $\begin{array}{l}\text { Aune et al. } \\
\text { (2011) }\end{array}$ & $\begin{array}{l}\text { Meta- } \\
\text { Analysis }\end{array}$ & - & Fiber intake & Breast cancer & $\begin{array}{l}\mathrm{RR} \text { for the highest } \\
\text { versus the lowest } \\
\text { consumption was } \\
0.93(95 \% \mathrm{CI} 0.89- \\
0.98, \mathrm{R}=0 \%) \text { for } \\
\text { dietary fiber }\end{array}$ \\
\hline 12. & $\begin{array}{l}\text { Coleman et al. } \\
\text { (2013) }\end{array}$ & $\begin{array}{l}\text { Meta- } \\
\text { Analysis }\end{array}$ & - & $\begin{array}{l}\text { Fiber diet } \\
\text { Gastric } \\
\text { cancer }\end{array}$ & $\begin{array}{l}\text { Esophagus } \\
\text { cancer }\end{array}$ & $\begin{array}{l}\text { There was a } \\
\text { significant } \\
\text { relationship between } \\
\text { fiber intake and the } \\
\text { incidence of } \\
\text { esophagus cancer }\end{array}$ \\
\hline
\end{tabular}

$\begin{array}{llllll}\text { 13. } \begin{array}{l}\text { Tang } \text { et al. } \\ \text { (2013) }\end{array} & \begin{array}{l}\text { Case- } \\ \text { Control }\end{array} & \begin{array}{l}\text { Oesophageal } \\ \text { cancer patients } \\ (\mathrm{n}=359)\end{array} & \text { Fiber diet } & \begin{array}{l}\text { Oesophageal } \\ \text { cancer risk }\end{array} & \begin{array}{l}\text { Higher fiber intake } \\ \text { decreases the risk of } \\ \text { oesophageal cancer }\end{array} \\ (\mathrm{p}=0.004)\end{array}$




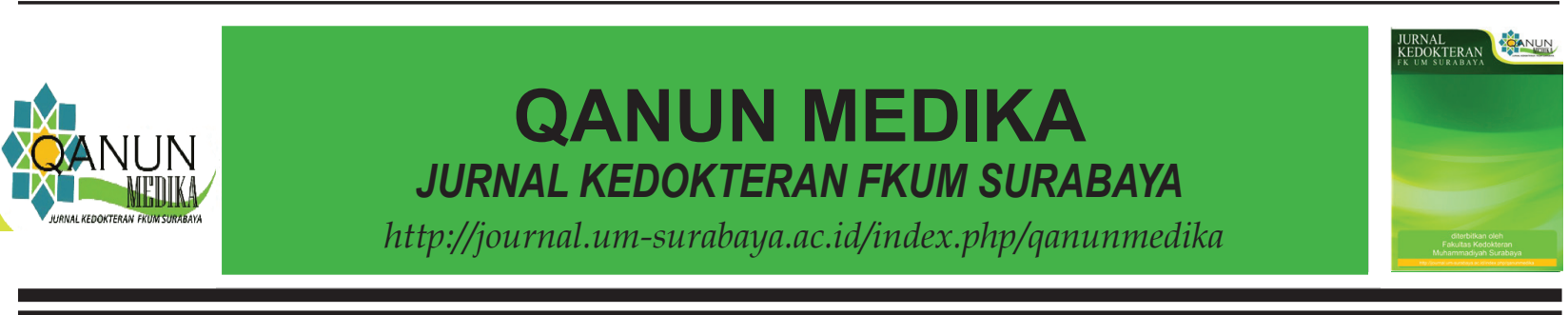

High Fiber Supplements And Diets To Overcome Non-communicable Diseases

The following studies have shown the influence of supplementation and fiber intake to treat these diseases. Alba et al. (2016) reported increase soluble fiber from Partially Hydrolysed Guar Gum (PHGG) on a normal diet towards type 2 diabetes patients and MetS improved cardiovascular and metabolic profiles by reducing $\mathrm{WC}, \mathrm{HbAlc}$, UAE and trans-FA. Routine increase and consumption of Dietary Fiber (DF) soluble causes a significant improvement in blood glucose levels, insulin resistance and metabolic profile, without improving the secretory function of Islets of Langerhans, during the short-term intervention period in DMT2 patients (Chen et al., 2016)

According to Post et al. (2012), interventions involving fiber supplementation for patients with type 2 diabetes mellitus can reduce fasting blood glucose and HbAlc. Metaanalysis studies proved increasing fiber intake also increased glycemic control, suggesting this should be considered to be a treatment of patients with type 2 diabetes (Silva et al., 2013).

For cancer, a dose-response analysis showed that each $10-\mathrm{g} / \mathrm{d}$ increase in dietary fiber intake was associated with a significant $7 \%$ reduction in breast cancer risk (Dong et al. (2015). A meta-analysis study by Kim and Je (2015) showed that RR for a $10 \mathrm{~g}$ /day increase in dietary fiber was 0.91 for CVD, 0,89 for $\mathrm{CHD}$, and 0.94 for all types of cancer.

\section{CONCLUSION}

Fiber intake is related to the incidence of non-communicable and can overcome some non-communicable diseases, especially cardiovascular diseases, diabetes mellitus, and cancer.

\section{REFERENCES}

Aune, D, Chan D S M., Greenwood, D C, Vieira, A R, Rosenblatt, D A N, Vieira, R.\& Norat, T. (2012). Dietary fiber and breast cancer risk: a systematic review and meta-analysis of prospective studies. 2011. Annals of Oncology 23: 1394-1402 doi:10.1093/annonc/mdr589

Bappenas. (2015). Rencana Pembangunan Jangka Menengah Nasional (RPJMN) 2015-2019

Bocanegra A, Bastida S, Benedí J, Ródenas S, Sánchez-Muniz F J. (2009). Characteristics and nutritional and cardiovascular-health properties of seaweeds. $J$ Med Food, 12: 236-258

Bonita, R, de Courten, M, Dwyer, T, Jamrozik, K \& Winkelmann, R. (2001). Surveillance of risk factors for non-communicable diseases: the WHO stepwise approach. Summary. Geneva: World Health Organization

Chen, C, Zeng, Y, Xu, J, Zheng, H, Liu, J, Fan, R. ,Zhu, W, Yuan, I, Qin, Y, Chen, S, Zhou, Y, Wu, Y, Wan, J, Mi, M \& Wang, J. (2016). Therapeutic effects of soluble dietary fiber consumption on type 2 diabetes mellitus. Experimental And Therapeutic Medicine 12: 1232-1242. DOI: 10.3892/etm.2016.3377

Coleman, H.G, Murray, L.J, Hicks, B., Bhat, S. K., Kubo, A., Corley, D.A, Cardwell, C. R., and Cantwell, M. M.. (2013). Dietary fiber and the risk of precancerous lesions and cancer of the esophagus: a systematic review and meta-analysis. Nutrition Reviews Vol. 71(7):474-482 doi:10.1111/ nure. 12032

Dall'Alba, V., Silva, F. M., Pec, J.,Antonio, A, Steemburgo T., Royer C.P., Almeida, J.C., Gross, J.L. \& Azevedo, J.A. (2013). 
Improvement of the metabolic syndrome profile by soluble fibre - guar. British Journal of Nutrition, 110, 1601-1610. doi:10.1017/S0007114513001025

Dong,J. Y, He, K, Wang, P, \& Qin, L Q. (2011). Dietary fiber intake and risk of breast cancer: a meta-analysis of prospective cohort studies. Am J Clin Nutr, 94:900-5 doi: 10.3945/ajen.111.015578

Fujii, H, Iwase, M, Ohkuma, T, Ogata-Kaizu, S, Ide, H, Kikuchi ,Y, Idewaki, Y, Joudai, T, Hirakawa, Y, Uchida, K, Sasaki, S, Nakamura, U. \& Kitazono, T. (2013). Impact of dietary fiber intake on glycemic control, cardiovascular risk factors and chronic kidney disease in Japanese patients with type 2 diabetes mellitus: the Fukuoka Diabetes Registry. Nutrition Journal, 12:159.doi:10.1186/1475-289112-159

Goff, H D, Repin, N, Fabek, H, El Khoury, D \& Gidley M. J. (2017). Dietary Fibre for Glycaemia Control: Towards a Mechanistic Understanding. Bioactive Carbohydrates and Dietary Fibre http://dx.doi. org/10.1016/j.bcdf.2017.07.005

Kementerian Kesehatan RI. (2013). Laporan Hasil Riset Kesehatan Dasar (Riskesdas). Badan Penelitian dan Pengembangan Kesehatan.

Kementerian Kesehatan RI. (2018). Laporan Hasil Riset Kesehatan Dasar (Riskesdas). Badan Penelitian dan Pengembangan Kesehatan.

Kim, Y \& Je, Y.(2015). Dietary fiber intake and mortality from cardiovascular disease and all cancers: A meta-analysis of prospective cohort studies. Archives of Cardiovascular Disease xxx, http://dx.doi. org/10.1016/j.acvd.2015.09.005
Mc Rae, M. P. (2017). Dietary Fiber Is Beneficial for the Prevention of Cardiovascular Disease: An Umbrella Review of Meta-analyses. Journal of Chiropractic Medicine ;xx:1-1 https://doi. org/10.1016/j.jcm.2017.05.005

Papathanasopoulos, A, Camilleri, M. (2010). Dietary fiber supplements: effects in obesity and metabolic syndrome and relationship to gastrointestinal functions. Reviews In Basic And Clinical Gastroenterology. Gastroenterology ;138:6572.e1-2

Park, Y, Subar, A F, Hollenbeck, A \& Schatzkin, A. (2011). Dietary Fiber Intake and Mortality in the NIH-AARP Diet and Health Study. Arch Intern Med, 171(12):1061-1068 doi:10.1001/archinternmed.2011.18

Post, R E, Arch, G, Mainous, A G, King, D E \& Simpson, K N. (2012). Dietary Fiber for the Treatment of Type 2 Diabetes Mellitus: A Meta-Analysis. $J$ Am Board Fam Med ,25:16 -23. doi: 10.3122/jabfm.2012.01.110148

Prosky, L.(2001). What is dietary fibre? A new look at the definition. En: Advanced dietary fibre technology. Blackwell ScienceOxford, UK. 2001; pp. 63-88.

Silva, F M. Kramer, C K, de Almeida, J C, Steemburgo, T., Gross, J L \& Azevedo. M J.(2012). Fiber intake and glycemic control in patients with type 2 diabetes mellitus: asystematic review with meta-analysis of randomized controlled trials. Nutrition ReviewsVol.71(12):790-801790 doi:10.1111/nure.12076

Tang, L, Xu F., Zhang, T., Lei J, Binns, C.W Lee, A. H. (2013). Dietary fiber intake associated with reduced risk of oesophageal. Cancer Epidemology 


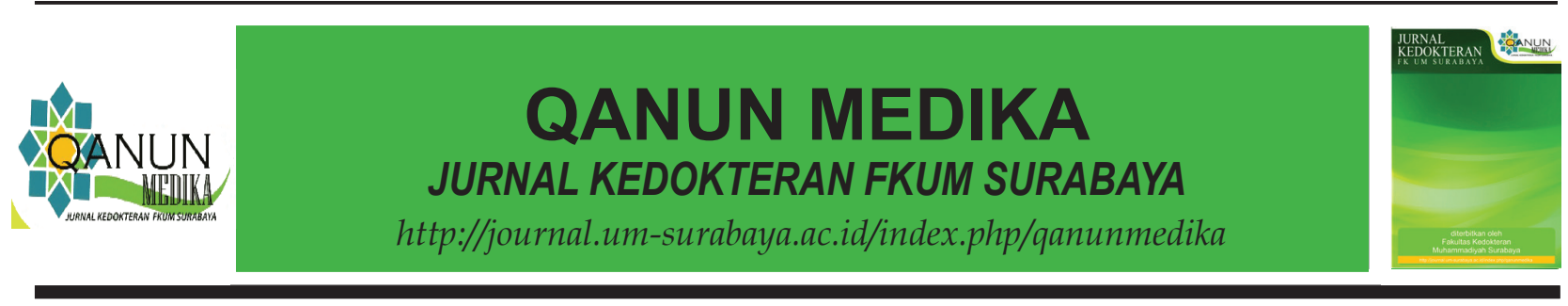

1877-7821/http://dx.doi.org/10.1016/j. canep.2013.08.012

Tayyem, R F, Al-Shudifat, A E, Johannessen, A, Bawadi, H A, AbuMweis, S S, Agraib, L M, Allhedan, S S, Haj-Husein, I \& Azab, M. (2017). Dietary patterns and the risk of coronary heart disease among Jordanians: A case-control study. Nutrition, Metabolism \& Cardiovascular Disease xx, 1e8. https://doi. org /10.1016/j.numecd.2017.10.026

Threapleton, D E, Greenwood, D C., Evans, C E L., Cleghorn, C L, Nykjaer, C, Woodhead, C, Cade, J E, Gale, C P, Burley, V J. (2014). Dietary fiber intake and risk of cardiovascular disease: systematic review and meta-analysis. $B M J$. volume 348 doi: 10.1136/bmj.f6879

Wei, B, Liu, Y, Lin, X, Fang, Y, Cui , J \& Wan, J. (2017). Dietary fiber intake and risk of metabolic syndrome: A meta-analysis Q4 of observational studies. Clinical Nutrition xxx 1e8. https://doi. org/10.1016/j.clnu.2017.10.019
Wu, Y H, Qian, Y F, Pan, Y W, Li, P W, Yang, J, Ye, X. H \& Xu, G. (2014). Association between dietary fiber intake and risk of coronary heart disease: A meta-analysis. Clinical Nutrition xxx 1e9. http://dx.doi. org /10.1016/j.clnu.2014.05.009

Xu, H, Rossi, M, Campbell, K.L, Sencion, G.L, Ärnlöv, J, Cederholm, T, Sjögren, P, Risérus, U, Lindholm, B, Carrero, J J.(2016). Excess protein intake relative to fiber and cardiovascular events in elderly men with chronic kidney disease. Nutrition, Metabolism \& Cardiovascular Diseases $\mathrm{xx}, 1-\mathrm{http}: / / \mathrm{dx}$. doi.org /10.1016/j. numecd.2016.02.016

Zhang, Z, Xu, G. Ma, M, Yang, J \&Liu, X. (2013). Dietary Fiber Intake Reduces Risk for Gastric Cancer: a Meta-Analysis. Gastroenterology, doi: 10.1053/j.gastro.2013.04.001. 